ELŻBIETA MarKIEWICZ

Spoteczna Akademia Nauk

$w £ o d z i$

\title{
IN DEFENSE OF HUMAN IDENTITY: THE REALITY OF GLOBALIZATION AS THE CAUSE OF MODERNIZATION OF MODERN EDUCATIONAL SYSTEMS
}

ABSTRAct. Markiewicz Elżbieta, In Defense of Human Identity: the Reality of Globalization as the Cause of Modernization of Modern Educational Systems [W obronie tożsamości człowieka - globalizacja jako przyczyna modernizacji współczesnych systemów oświaty]. Studia Edukacyjne nr 45, 2017, Poznań 2017, pp. 281-290. Adam Mickiewicz University Press. ISSN 1233-6688. DOI: 10.14746/se.2017.45.19

The article In Defense of Human Identity: the Reality of Globalization as the Cause of Modernization of Modern Educational Systems is an attempt to reflect on the role of the educational process in the context of the value system offered in the modern world. It appears that authentic human participation in the reality of global and involuntary compliance with the directives of globalism is both a crisis of identity, of its existence, values, norms, and all human activities. Efforts taken to demonstrate the value of dogma, which carries with it an affirmation of the modern world, and conformist standards of conduct, is to notice the risk of objective truth about man and reality. Civilization implies in fact a kind of order to eradicate what is human. The human drama shows an almost total devotion to the values of functionalism and utility. Therefore, it is vital for modern education to return to the personal dimension of human existence. This accomplishment, a full range of education, which means clarifying the challenges confronting it, is only possible with recognizing and highlighting the personal status of the man based on the personalistic norm. This article helps the contemporary human being to realize the importance of learning to respect human dignity and to protect the identity of a mature man.

Key words: education, modern educational system, culture, man, identity, globalization

Parenting is a comprehensive update of personal human potentiality. ${ }^{1}$

\section{Introduction}

We live in time of universal globalism. This is the period in which the permanent formation of new patterns of behavior, standards of conduct and

${ }^{1}$ E. Drążek, I. Skawina, Anthropological contexts of education - modern utilitarianism axiological and educational principles to life, [in:] Time for education. Key contexts and conditions, Ed. B. Piątkowska, Wałbrzych 2009, p. 118. 
categorical demands of contemporary reality, implies specific challenges and problems. Globalism in fact, determines consistently all areas of human culture and science, it becomes not only the cause of the new order, but also defines this reality, which challenges the modern man and the tasks he must meet. Therefore, there arises the immediate sense of uncertainty and risk associated with each dimension of human existence. There is a real danger of perdition own personal identity in favor of conformist agenda of the new global reality. It seems that the fullest reflection of this state is the education.

This is because the educational institutions and structures, globalism poses new and difficult tasks, awaiting preparation promoted by itself, a universal model of life and shapes its adaptability to changing conditions. It thus appears that it is the culture and education, which should set goals and contemporary aims of acting and conducting which have the greatest impact on the acquisition of knowledge and skills which are necessary to man for global activity. Meanwhile, we see that (...), classical (ie, current - Markiewicz) systems and forms of education are lagging behind the economic and social realities.

New technologies are only a tool, an instrument that - helping to solve problems - they may also contribute to increase of inequality." 2 There was, therefore, the educational situation has reached this threshold, where the only way for the further development and evaluation of the actual implementation of reforms to the global reality is taking ownership, which will serve the welfare and protection of man as a person. Real changes in education must be in aim to prepare people not only to benefit from the achievements of modern civilization, but primarily to the creative participation in the process of its continued existence and development.

This means that the primary task, which must face the educational systems is an appropriate preparation of the world public to the taking the benefits of globalization, combating the negative and above all to help find a place in the world of culture, understanding both it own, and the current degeneration and functionality its areas in the name what is universal. ${ }^{3}$

\section{Condition and tasks of the modern educational system}

The reality of a global effort to root in the field of education twenty-first century, is a sine qua non for the concomitant overcome the crisis which has

\footnotetext{
${ }^{2}$ F. Mayor, Un monde nouveau, Ed. W. Rabczuk, Warsaw 2001, p. 378.

${ }^{3} \mathrm{~K}$. Wielecki, Youth and education after the great change, [in:] Education and youth towards the civil society, Ed. K. Przyszczypkowski, A. Zandecki, p. 117.
} 
struck modern educational systems, as well as further development of the education. There is no separate sound of changes, progress and activity that is observed in the field of education and is related to the constant conviction of the necessity of so-called. teaching and/or conservative learning. ${ }^{4}$ Hence there is a specific distance between the rapidly growing complexity of the world and possibility to meet its. As a result, typical for the current deficiencies in education, especially a conservative learning, hostile to innovation and alternatives solutions, reduces the human capacity to make decisions on global matters. ${ }^{5}$ This means that man is totally devoid of actual control over the progress, which is the result of inaction, lack of awareness of life and do not use elements of moral or ethical. So in spite of all attempts made to reform, the development of education, sees the evolution of educational apathy, results and achievements. Still In fact, modern education, and growing do not correspond to current needs, both at the content and learning objectives, and methods and organization. ${ }^{6}$ As rightly Pachocinski: „(...) the traditional school is not prepared to take the challenges of modern civilization. Reacts too slowly to changes". ${ }^{7}$ This apparent disparity between the current state of education and the requirements of the constantly evolving global realities, not only accentuates the crisis of modern educational systems, but at the same time the need to undergo a thorough reconstruction. ${ }^{8}$ Thus, modern education must be a specific process of education of persons. Its uniqueness should be reflected in the overall implementation of the evolution of human beings in the course of a lifetime with a view to an integral development of the mental, physical, affective, moral and spiritual. It should be a process that includes not only the transfer of knowledge and skills, broad cultural values, but is also inspiring creative and open attitude, independence of thought and the capacity for continuing self-education. ${ }^{9}$ This is therefore to develop a reasonable ability of awareness and critical evaluation towards the modern world, his constant knowledge, analyzing and interpreting and actually creative building the future of education which will meet the needs of such a global world.

\footnotetext{
${ }^{4}$ We are talking about the traditional model of teaching and/or learning, where the acquired fixed outlooks, methods and rules that allow to proceed in the face of known and reproducible. This model is also useful in maintaining the existing system or established way of life. It is characterized by having a durable expression in the adaptation and passivity.

${ }^{5} \mathrm{Cz}$. Kupisiewicz, The thing about education: selection of studies and articles, Warsaw - Radom 1999, p. 82.

6 Ibidem.

${ }^{7}$ R. Pachociński, Education and work in an era of globalization, Warsaw 2006, p. 35.

${ }^{8}$ Cz. Kupisiewicz, The thing about education, p. 83.

${ }^{9}$ I. Wojnar, World decade of cultural development - new proposals for education, [in:] The challenges of Education XXI century, Ed. I. Wojnar, J. Kubin, Warsaw 1997, p. 141.
} 
In practice, it is desirable to adjust the modern educational systems to the dynamic global reality: to the new conditions of cultural, social and economic issues and the strengthening of the educating - by the global education - a global society, was based on generally applicable education for the future by shaping and promoting a educational culture as the dominant culture. This is an urgent need for change, expressed in the adaptation of existing educational systems, has to depend mainly on the promotion and individualizing the education that is increasing its effectiveness and "(...) subordinating the needs of educating society, whose main task is to build our times" ${ }^{10}$ It means indoctrination of global educational values, which are teaching and learning to live together, activation of knowledge and action to fully exploit the potentiality, which includes modern civilization.

Comprehensive utilization of capacity, which are inherent in modern civilization is only possible with the appropriate level of preparation and knowledge, which cannot but be communicated in a closed period of time, but must be acquired throughout life. There is a profound sense of password "learning to be" as learning a new dimension that is becoming a lifelong, permanent process to constantly changing life situations. More and more, in fact, the pace of changes and ever-new situations that they face is a modern man, require innovative approaches in teaching, that such conduct of the education that will find solutions in new and unusual situations, not only in familiar and repetitive, as in the teaching of traditional, conservative. Jacques Delors ${ }^{11}$ writes in the global Club of Rome report that the modern education should be based on four basic pillars:

1. learn to know,

2. learn to act,

3. learn to live together,

4. learn to be.

So primary, immutable, objective and purpose of modern education is established in the Universal Declaration of Human Rights, the rule of the comprehensive development of man-pupil. ${ }^{12}$ This development, occurring in the course content, should resign and totally rejected the existing encyclopedism teaching for over-formalism and of the curriculum that is comprehensive presentation and knowledge transfer. With regard to the teaching methods used, it should be

(...) primarily to prepare students for self-perception, formulate and solve specific problems of theoretical and/or practical to use the knowledge they have acquired in

${ }^{10}$ Cz. Kupisiewicz, The thing about education, p. 83.

11 Ibidem.

12 The Universal Declaration of Human Rights (adopted and proclaimed General Assembly resolution ONZ 217 A (III) on 10 December 1948), art. 26, p. 1-3. 
order to acquire new knowledge and skills to think about alternative and innovative to anticipate events and processes of school programs, and even - in appropriate circumstances - outside these programs. ${ }^{13}$

It is therefore not only to resolve organizational dilemmas: whether to train as an object, or integrated, or to cling to the current model of transmit reproductive, or replace it with a type of generative, etc., but more important is to stress education and defense of raising and shaping the student - person. This means accurate targeting of education at independence of thought and action the student's cognitive activity, group work, study skills, formulating and solving problems, and individualization of pace, content and working time. Consequently, it is well targeted to the student - the person, the use of the content, methods, means and forms of education seems to be the most urgent task of education.

\section{Freedom education to culture education}

In the context of global education, diagnosis, and current challenges to the modernization of educational systems, we discover a fundamental problem concerning the nature of modern education. This problem is, namely, the lack of a rational vision of education - the lack of philosophy of education, which on the one hand raises the question of the meaning of any intended changes in education, the other on a reasonable basis for the training. Against this background, there is a project which would justify the whole question now emerging is the proposal to adopt the philosophy based on the so-called. libertarian education. This training covers the three basic dimensions: education for freedom, for liberty and freedom. The first of these, having a humanistic nature, assumes over cultural form of human. That is, both to develop the skills necessary to implement the global civilization, their own - personal tasks and goals, as well as understanding and acquiring a knowledge of contemporary culture. „Indeed, this culture will make the unit more aware of both their own heritage and tradition of learning. This will allow it to recognize different patterns of the good life, which will be able to build its own identity." ${ }^{14}$ Hence, education about freedom justifies the rational basis of human identity, is an education on the development of human identity. Such an education, is also a realization of the second aspect: the freedom of education. It is not enough education about freedom itself. Man, in fact, should be educated with freedom. This implies the need to develop an appropriate

\footnotetext{
${ }^{13} \mathrm{Cz}$. Kupisiewicz, The thing about education, p. 92.

${ }^{14}$ M. Łuczewski, Liberal Education, Mishellanea, 2000, 1, p. 79.
} 
methodology for capturing the knowledge of education that is operative to avoid in the education of indoctrination and manipulation. This methodology, therefore, should consider the possibility of student decision-making on the choice of the scope of learning objects, materials, etc. and to develop skills, thinking and action - including arguing, command and inference. It seems so important to set out clear objectives and methods of training which would be a point of reference, and also protection against falling into unreflective conformism threatening their own personal awareness "I".

Discussed the pillars of education are in line with the last dimension of libertarian education, i.e. education for freedom, understood as the maturity and responsibility in action and proceedings (both personal and social). It is therefore to develop a capacity, and simultaneously prepare for skillful exercise of freedom. This ability, in a global reality that surrounds us, is inextricably coupled with the culture of education, is a kind of liberation from the homogenization, marginalization and the continued depreciation of education in the culture of their experience: their own identity and sovereignty. Such an understanding of libertarian education, grew out of the personality understanding of culture, which is defending the human dignity updates at the same time, the personality of a free man. „Built on such assumptions the culture (...) is able to overcome the growing existential threat now characterized the human and the world". ${ }^{15}$ Culture of modern education thus requires the introduction of valuable and objective global education, inclusive education, the development of a culture of life worthy and valuable in the full human identity. That is, the education of man through the process of participatory learning and development equal to basic human action, and the relationship to the person. ${ }^{16}$ In practice, doing so to elaborate, culturally specific (so as to freedom and education), forms the scientific moral sensibility, which trains a man of both his intellect, imagination and empathy within the community of libertarian education, which are on equal footing: teacher and pupil. This process of education to create a culture based on higher than utilitarian, values, shaping and improving proven in deeds and attitudes and personality of its autonomy and self-realization. Hence, the freedom to shape the right resting on moral values, all the educational activities of contemporary civilization, education, must relate to the subjective human being - pupil. This does not mean the closure of educational activities within the limits of the theory that the same aspect of individual, social and moral. First of all, the point is to stress the practical dimension of the libertarian cultural education expressed in the unfettered and unrestricted movement between the theory - that the

${ }^{15}$ Jan Paweł II, In the name of the future of culture, faith and culture, [in:] Man, education, culture, Ed. F. Adamski, Kraków 1993, p. 207.

${ }^{16}$ K. Wojtyła, Man in the field of liability, Rome - Lublin 1991, p. 86. 
field in which are designed a new approaches, and practice - that the plane, which is carried out these solutions or ideas. This implies tight cooperation to supplement and equivalent vitae activia and vitae contemplativae. With this in mind it should be noted that, since the essence of libertarian education, formed by cultural upbringing (i.e. "in" culture and "by" culture) is a permanent transformation of human nature - ward, it is necessary to be aware of proper vision of man himself.

Cultural vision of man, emphasizes the element of eternity, the limitations, but undeniable dignity, provides the philosophical and social base of his development as a person who is in a certain relationship with the world of things and other people. The model of culture embedded in these values, considering that the primary and essential task is to educate, not going through the human acts such a manner that was becoming more human, to more "was" not just more "have". ${ }^{17}$

Current libertarian education and culture education should therefore arise from the module: culture - education - personality. A person who is alive in culture and culture creates, which affects the shape of his personality. Based on the cultural goods, the understanding and the experience of having in it a source of value, man develops his personality and a system of moral conduct.

\section{Axiological education as a tendency to moral action}

Material and mental human activities, with their creations, creating, dynamic, human reality - the global reality. In this reality, man is totally rooted which means that he in a responsible manner is getting mature in the direction of self-awareness and independence (as a partnership, as well as cultural). This authentic personal readiness to function in the global structure is, in some way, limited by the reality of their norms and values, which should be seen as a real threat to the man. Indeed global order, shall, as a guiding principle, dynamic and "(...) the immediate transformation and intensification of all areas of social life including particularly the structures of human activity" ${ }^{18}$ Linked to this is the progress that has spanned the universal viability, an actual law of prosperity. And since, the condition to effectiveness of any action is accurate determination of objectives, hence, forced by the reality, the purpose of man is its usefulness. Promoted utilitarianism, implies a slow, but effective depreciation of

${ }_{17}$ Jan Paweł II, In the name of the future, p. 71.

18 E. Drążek, Utilitarian Humanity: between civilization and the axiology of moral philosophy, D. Michałowska, S. Chris (ed. Teachings), Philosophical Notebooks, 2009, 14-15, p. 66-67. 
the people for its functionality. This means that the social usefulness of the unit determines its identity. As a result, a man falls into a special trap of individualism, i.e. the total abandon of objective, independent of individual circumstances, moral principles, in order to complete the liberation of all moral constraints. To avoid this, it is necessary to develop a sensitivity axiological as a tendency to sensitize the objective value. Sensitivity to this can develop and strengthen the so-called. axiological education as learning to know, understand and experience the adequate values. We must therefore conduct the education aimed at the empowerment and the support of man in his maturity, the understanding and experience of his experience. It means hard work on the shaping, acquiring and improving awareness of the axiological dimension of both the man as a person and the human reality. This is what determines the proper hierarchy of values and human action, the conduct and the attitude. Therefore, the task of modern education axiological is in the highest degree of emphasis this overestimated value which is a man and his life, mental development, self-realization, freedom, subjectivity and identity. ${ }^{19}$ Recognition of human being - a person as a baseline value is equivalent to the affirmation of moral conduct that is fully consistent with human nature. This means that the moral acts, full acceptance towards fulfilling one's own humanity - defining their own identity. Therefore, it is the same man who is particular, the guiding moral standard of all its acts. Indeed a person, and specifying: a personal dignity, always inseparable, and equally invariably expressed as the moral norm that one side is in the same subject of action, and from that entity is dependent, on the other hand, as an entity outside the inherent action and from it is independent. Only superficially it appears to be a contradiction. Well, if the personal dignity of the human person is clocked as the standard contained in the entity and the function of it, then "(...) self-dignity of the person's acting for him, is always (directly or indirectly, solely or jointly with other recipients of action) the norm of morality, inside as well as outside it: in every other personal or non-personal recipient of activity". ${ }^{20}$ Simultaneously, human dignity should trample as the norm, which is independent on the same entity in the sense that is attributed to his knowledge as a specific-to-read and affirmated item. This means that a full highlight of the uniqueness of the person acting as, in itself and by itself combines fidelity to the realization of objective goods while being faithful to itself. The status of a man as an unnecessary being and a casual being has shown the necessity of moral action. ${ }^{21}$ A person can carry out only "in" the deed which complies and "by" this action, which results from its the decision-making acts including the choice of certain values and norms

${ }^{19}$ T. Lewowicki, Transformation of Education, Warsaw 2002, p. 42.

${ }^{20}$ T. Styczeń, J. Merecki, ABC Ethics, Lublin 2007, p. 38.

${ }^{21}$ M.A. Krąpiec, Moral philosophy, [in:] The Universal Encyclopedia of Philosophy, t. 3, Ed. A. Maryniarczyk, Lublin 2007, p. 494. 
of action. The present content and manner of human activities, namely the validity of the measures are per se determined by the subject structure which is the nature of the person. Effective design requires knowledge of the realization of human nature, and to adapt its activities, in particular, understanding and acceptance of an objective hierarchy of goods set out by the structure of the human person. In antic-axiological structure of the human person is necessary to distinguish the good - the dignity that has the same person from the goods related to its structure, for which is proposed to name for the property of person. Among these, in turn, is necessary to distinguish the good related to its structu$\mathrm{re}$, as the existence (life) and not necessarily good, such as bodily integrity (eg, the possession or lack of certain organs). Understanding this hierarchy allows for the formulation of generally valid rules of conduct morally legitimate (natural law). Their general validity (ie, the universality and constancy) has its basis in the immutability of the fundamental structure of the human person - the human nature. ${ }^{22}$

With this in mind, education should realize axiological truth about humanity, which is a situation arising "in" and "by" human behavior and it is the expression of consciousness of "self" in a free and worthy action. Hence, in the field of educational responsibility is important to direct every action towards the parental relationship which is the development and shaping of personal maturity supported by the respect of objective norms and moral principles.

\section{Conclusion}

The current global environment is the flexible meristem, which determines the actual location, boundaries and cultural structure of human activity. Against this background, the specific role is connected to modern education which is actively trying to keep up with the educational equaling (to emerging instantly) the requirements of civilization. These trends, suggest turning towards the objective truth about the man - his identity and personal dignity. Personal dimension of human existence, mainly the actions and conduct, constitutes an integral educational demands to determine the basis for any reform of modern education systems for the protection of human identity in a changing world. This means that the main task of all educational activities should be to promote, rooted in personalism, moral norm, which is participating in human action emphasizes both the dignity and freedom of functioning properly understood. Therefore, parental personalism is an attitude of positive influence on the formation and maturation of human relationships

\footnotetext{
${ }^{22}$ T. Styczeń, J. Merecki, ABC Ethics, p. 34-35.
} 
by taking into account where a person seeks to develop a real, full, human potential. Consequently, the priority of that attitude, not violating the man's co-participation in the progress of the global reality, born inviolable truth that "man is not only the perpetrator of his actions, but for these acts is also in some way, "the creator himself". ${ }^{23}$

\section{BIBLIOGRAPHY}

Drążek E., Utilitarian Humanity: between civilization and the axiology of moral philosophy, D. Michałowska, S. Chris (ed. Teachings), Philosophical Notebooks, 2009, 14-15.

Drążek E., Skawina I., Anthropological contexts of education - modern utilitarianism axiological and educational principles to life, [in:] Time for education. Key contexts and conditions, ed. B. Piątkowska, Publishing House of The Angelus Silesius University of Applied Sciences in Wałbrzych, Wałbrzych 2009.

Jan Paweł II, Centesimus annus, nr 41, Rzym 1991.

Jan Paweł II, In the name of the future of culture, faith and culture [in:] Man, education, culture, Ed. F. Adamski, Publishing House of WAM, Kraków 1993.

Krąpiec M.A., Moral philosophy, [in:] The Universal Encyclopedia of Philosophy, t. 3, Ed. A. Maryniarczyk, Publishing House of PTTA, Lublin 2007.

Kupisiewicz Cz., The thing about education: selection of studies and articles, Publishing House of Higher Pedagogical School Teachers' Union in Warsaw, Warsaw - Radom 1999.

Lewowicki T., Transformation of Education, Publishing House of ZAK, Warsaw 2002.

Łuczewski M., Liberal Education, Mishellanea, 2000, 1.

Mayor F., Un monde nouveau, Ed. W. Rabczuk, Fundation for Educational Studies and Research, Warsaw 2001.

Pachociński R., Education and work in an era of globalization, Publishing House of The Educational Research Institute, Warsaw 2006.

The Universal Declaration of Human Rights (adopted and proclaimed General Assembly resolution ONZ 217 A (III) on 10 December 1948), art. 26, p. 1-3.

Styczeń T., Merecki J., ABC Ethics, Publishing House of KUL, Lublin 2007.

Wielecki K., Youth and education after the great change, [in:] Education and youth towards the civil society, Ed. K. Przyszczypkowski, A. Zandecki, Publishing House of Adam Mickiewicz University, Poznań - Torun 1996.

Wojnar I., World decade of cultural development - new proposals for education, [in:] The challenges of Education XXI century, Ed. I. Wojnar, J. Kubin, Publishing House of Forecasting Committee "Poland 2000 Plus", Warsaw 1997.

Wojtyła K., Man in the field of liability, Publishing House of The Institute of John Paul II Catholic University of Lublin, Rome - Lublin 1991.

${ }^{23}$ Jan Paweł II, Centesimus annus, nr 41, Rzym 1991, p. 12. 